Research Article

\title{
Investigation of Convaren's stimulating effect on immune organs of mice
}

\author{
Komila Porsokhonova*, Rustam Agzamov
}

\begin{abstract}
Department of Pharmacology, Faculty of Treatment, Tashkent Medical Academy, Tashkent, Uzbekistan
\end{abstract}

Received: 11 May 2015 Accepted: 02 July 2015

*Correspondence to: Komila Porsokhonova, Email: kamila.petrovna@ gmail.com

Copyright: (C) the author(s), publisher and licensee Medip Academy. This is an openaccess article distributed under the terms of the Creative Commons Attribution NonCommercial License, which permits unrestricted noncommercial use, distribution, and reproduction in any medium, provided the original work is properly cited.

\begin{abstract}
Background: Investigation of Convaren's immunostimulating action on white mice used to prove its effectiveness as a new immunomodulatory drug that then may be used by humans for treatment of infectious, tumor, systemic, and other diseases followed by decrease of immune system function.

Methods: In this investigation were observed immunomodulating effects of Convaren on immune organs of mice (spleen, thymus, mesenteric lymph nodes, bone medulla). All effects were estimated due to the amount of antibody producing cells (APC) in their spleen, amount of APC calculated on whole organ and on $10^{6}$ spleen cells, amount of nucleus containing spleen cells, common amount of nucleus containing cells in thymus, mesenteric lymph nodes, and bone medulla.

Results: Convaren in doses 50 and $100 \mathrm{mg} / \mathrm{kg}$ significantly increases amount of cells in thymus and bone medulla, but significant increase of cell amount in lymph nodes was observed just with dose $50 \mathrm{mg} / \mathrm{kg}$. It shows that dose $50 \mathrm{mg} / \mathrm{kg}$ is optimum, with which the cell proliferation processes in central and peripheral immune organs are expressed maximally. Smaller dose of Convaren has a little better stimulating effect than the higher one.

Conclusions: New drug Convaren has a high immunostimulating activity in mice's organisms. Due to its low toxicity, availability of raw materials and not hard production and transportation Convaren may be a cost-effective drug for the Asian region.
\end{abstract}

Keywords: Convaren, Immunomodulator, Convolvulus arvensis L., Proliferation of immune cells

\section{INTRODUCTION}

The problem of immune therapy is interesting for physicians of all specialties because of the steady growth of infectious and inflammatory diseases, prone to chronic and recurrent flow on the background of the low effectiveness of basic therapy of malignant tumors, allergic, systemic diseases, viral infections, causing a high incidence of mortality and disability. ${ }^{1}$ In addition to somatic and infectious diseases on the human body adversely affect social, environmental factors, medical interventions, in which the first to suffer is the immune system, which can cause the development of secondary immunodeficiencies. Despite the constant improvement of methods and tactics of the basic therapy of diseases and the use of deep reserve drugs with the involvement of non-medical methods, the effectiveness of treatment remains at a fairly low level. One of the urgent problems of modern pharmacology is the discovery of improved immunomodulatory agents that combine such important characteristics as the effectiveness and safety in usage. ${ }^{2}$ In this regard, our attention attracted the drug codenamed Convaren, which is the sum of biologically active substances extracted from plants Convolvulus arvensis $\mathrm{L}$.

C. arvensis $\mathrm{L}$. has been long used in folk medicine as a remedy having anti-inflammatory, hypotensive, laxative, and myotropic effects. ${ }^{3}$ There also was found its immunomodulating effect. ${ }^{4}$

Pharmacologically, water extract (aerial parts) of C. arvensis is rich in high molecular weight proteoglycan mixture, and has potent anti-angiogenesis and stimulating effects (immune system). ${ }^{5}$ Phytochemical studies on this plant showed the presence of saponins, steroids, flavonoids and alkaloids, proteins and lipids. It was also found to contain the pyrrolidine alkaloids cuscohygrine and hygrine. ${ }^{6}$

Convaren is a new drug synthesized in Uzbekistan on the base of $C$. arvensis L. Nowadays, it is known that Convaren has an anti-inflammatory, analgesic, antipyretic, and immunomodulating effects. 


\section{METHODS}

In experiments were used white mice with mass 20-22 g, which were immunized by sheep erythrocytes (SE) in mouse dose $2 \times 10_{6}$ per mouse.

The animals were separated on three groups by 6 . The first group was control: Mice were immunized by SE. Second group of mice were immunized by SE and Convaren in dose $50 \mathrm{mg} / \mathrm{kg}$ during 4 days. Third group got SE and Convaren in dose $100 \mathrm{mg} / \mathrm{kg}$ during 4 days.

On the $5^{\text {th }}$ day of immunization, mice were killed. There was counted amount of antibody producing cells (APC) in their spleens (by Jerne and Nordin method, 1963), amount of APC was calculated on whole organ and on $10^{6}$ spleen cells. ${ }^{6-8}$ There was calculated common amount of nucleus containing spleen cells (NCSC). In central (thymus, bone medulla) and peripheral (mesenteric lymph nodes) immune organs was calculated the common amount of nucleus containing cells counted (NCC).

\section{RESULTS}

In spleens of the control mice group produced $8333.3 \pm 468.8$ APC (Table 1). In a group of mice received Convaren in dose $50.0 \mathrm{mg} / \mathrm{kg}$, the amount of APC per spleen significantly increases in $1.81(15083.3 \pm 847.9)$. Under the action of Convaren in dose $100 \mathrm{mg} / \mathrm{kg}$ amount of APC in spleen significantly increases in 1.54 and amounts $12850.0 \pm 726.1$. There was no observed significantly difference between the stimulating activity of different doses of the drug, but smaller dose have a little more expressed stimulating effect on APC proliferation.

After recalculation of APC on 1 million spleen cells was established that this index in control group equal $28.9 \pm 3.5$, in groups received Convaren in doses 50 and $100 \mathrm{mg} / \mathrm{kg}$, their amount significantly increases by $1.43(41.2 \pm 4.4)$ and $1.53(44.2 \pm 6.1)$ times, respectively.

As shown in Table 1, the common amount of NCSC in the control group is $307.5 \pm 32.7 \times 10^{6}$. In groups receiving Convaren in doses, 50 and $100 \mathrm{mg} / \mathrm{kg}$ amount of NCSC not significantly increases by 1.25 and 1.04 times. Therefore, under the action of Convaren is observed tendency to increase of common spleen cell amount.

Then was investigated the effect of Convaren on common amount of NCC in central (thymus, bone medulla) and peripheral (lymph nodes) immune organs of immunized mice (Table 2).

As shown in Table 2, in thymus of the control mice group was found $67.6 \pm 1.4 \times 10^{6}$ cells. In groups of mice received Convaren in doses 50 and $100 \mathrm{mg} / \mathrm{kg}$, common amount of thymus cells significantly increases by 1.21 times $\left(81.8 \pm 2.1 \times 10^{6}\right)$ and 1.15 times $\left(77.7 \pm 1.9 \times 10^{6}\right)$, respectively. Smaller dose of Convaren has a little better-stimulating effect, but there was not observed a significant difference between activities of different doses. Therefore, Convaren has an ability to increase an amount of mice's thymus cells.

Similar data were obtained in the study of the Convaren's action on another central immunity organ - bone medulla. In the control group, the number of cells in the bone medulla is $13.4 \pm 0.5 \times 10^{6}$. Both doses significantly increase the number of bone medulla cells by dose $50 \mathrm{mg} / \mathrm{kg}$ - by 1.22 times $\left(16.3 \pm 0.7 \times 10^{6}\right)$, at a dose of $100 \mathrm{mg} / \mathrm{kg}$ - by 1.18 times $\left(15.8 \pm 0.6 \times 10^{6}\right)$, respectively. As in studies of cell numbers in the thymus a smaller dose of Convaren has somewhat greater stimulatory effect than the higher one.

As can be seen in Table 2 the total number of cells in the mesenteric lymph nodes of immunized mice in the control group was $24.2 \pm 1.2 \times 10^{6}$. In the group of mice received

Table 1: Influence of Convaren on immune answer on $\mathrm{SE}$ in mice $(\mathrm{M} \pm \mathrm{m}, \mathrm{n}=6)$.

\begin{tabular}{|c|c|c|c|c|c|c|c|}
\hline \multirow[t]{2}{*}{ Group } & \multirow{2}{*}{$\begin{array}{c}\text { Dose of drug } \\
\mathrm{mg} / \mathrm{kg}\end{array}$} & \multirow{2}{*}{$\begin{array}{l}\text { Amount of } \\
\mathrm{NCSC} \times 10^{6}\end{array}$} & \multirow[t]{2}{*}{ CI } & \multicolumn{4}{|c|}{ Amount of APC on } \\
\hline & & & & Spleen & CI & $10^{6}$ spleen cells & CI \\
\hline Control & - & $307.5 \pm 32.7$ & - & $8333.3 \pm 468.8$ & - & $28.9 \pm 3.5$ & - \\
\hline Convaren & 50.0 & $383.3 \pm 35.6$ & +1.25 & $15083.3 \pm 847.9^{\mathrm{a}}$ & +1.81 & $41.2 \pm 4.4^{\mathrm{a}}$ & +1.43 \\
\hline Convaren & 100.0 & $318.3 \pm 45.0$ & +1.04 & $12850.0 \pm 726.1^{\mathrm{a}}$ & +1.54 & $44.2 \pm 6.1^{\mathrm{a}}$ & +1.53 \\
\hline
\end{tabular}

${ }^{a}$ Authentically to 1 g. NCSC: Nucleus containing spleen cells, CI: Correlation index, APC: Antibody producing cells

Table 2: Influence of Convaren on cell amount in central and peripheral immune organs of mice $(M \pm m, n=6)$.

\begin{tabular}{|lccccccc|}
\hline Group & $\begin{array}{c}\text { Dose of drug } \\
(\mathbf{m g} / \mathbf{k g})\end{array}$ & $\begin{array}{c}\text { Thymus } \\
\text { cells } \times \mathbf{1 0}^{\mathbf{6}}\end{array}$ & CI & $\begin{array}{c}\text { Bone medulla } \\
\text { cells } \times \mathbf{1 0}^{\mathbf{6}}\end{array}$ & CI & $\begin{array}{c}\text { Lymph node } \\
\text { cells } \times \mathbf{1 0}^{\mathbf{6}}\end{array}$ & $\begin{array}{c}\text { CI } \\
\text { Control }\end{array}$ \\
\hline Convaren & 50 & $67.6 \pm 1.4$ & - & $13.4 \pm 0.5$ & - & $24.2 \pm 1.2$ & - \\
\hline Convaren & 100 & $81.8 \pm 2.1^{\mathrm{a}}$ & +1.21 & $16.3 \pm 0.7^{\mathrm{a}}$ & +1.22 & $28.7 \pm 1.0^{\mathrm{a}}$ & +1.19 \\
\hline
\end{tabular}

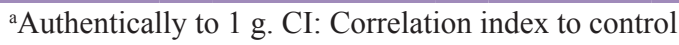


Convaren in dose $50 \mathrm{mg} / \mathrm{kg}$, the number of cells in the lymph nodes was significantly increased by 1.19 times $\left(28.7 \pm 1.0 \times 10^{6}\right)$. Under the influence of Convaren in dose $100 \mathrm{mg} / \mathrm{kg}$, the number of cells in the lymph nodes insignificantly increased by 1.16 times $\left(28.0 \pm 1.7 \times 10^{6}\right)$.

\section{DISCUSSION}

Traditionally, C. arvensis is used for treating jaundice, ${ }^{9}$ and its ethanol extract is said to be rich in flavonoids including quercetin and kaempferol. ${ }^{10}$ The phytochemicals are responsible for various scientific effects such as anti-angiogenesis, cytotoxicity, as well as immune stimulatory. 5,11

It is known that Convaren has an anti-inflammatory, antitumor, analgesic, antipyretic, and immunomodulating effects. ${ }^{12}$ Earlier the main attention was paid to the antiangiogenic (anti-tumor) effect of $C$. arvensis, ${ }^{13-15}$ but nowadays also increases the role of its immunomodulatory action. $^{16}$

There are many types of immunomodulators, that's why we investigated the mechanism of Convaren's action on the immune system of white mice. ${ }^{17}$ Our investigation shows that Convaren in doses 50 and $100 \mathrm{mg} / \mathrm{kg}$ significantly increases amount of cells in thymus and bone medulla, when significant increase of cell amount in lymph nodes was observed just with dose $50 \mathrm{mg} / \mathrm{kg}$. It shows, that dose $50 \mathrm{mg} / \mathrm{kg}$ is optimum, with which the cell proliferation processes in central and peripheral immune organs are expressed maximally. Smaller dose of Convaren has a little better stimulating effect, than the higher one. Therefore, bone medulla as the thymus is sensitive to Convaren's stimulating effect.

\section{Funding: No funding sources}

Conflict of interest: None declared

Ethical approval: This study was approved by

Pharmacological Committee of Republic of Uzbekistan,

has a patent of Republic of Uzbekistan No. 4850

\section{REFERENCES}

1. Khan MM. Immunopharmacology. New York: Springer Science+Business Media, LLC; 2008: 266-28.

2. Little M, editor. Recombinant Antibodies for Immunotherapy. Cambridge: Cambridge University Press; 2009: 434-419.

3. Murad W, Ahmad A, Gilani SA, Khan MA. Indigenous knowledge and folk use of medicinal plants by the tribal communities of Hazar Nao Forest, Malakand District, North Pakistan. J Med Plants Res. 2011;5(7):1072-1086.

4. Bowait ME. Albokhadaim IF, Homeida AM. Immunostimulant effects of bindweed (Convolvulus arvensis) extract in rabbits. Res J Pharmacol. 2010;4(2):51-4.

5. Mahmoudi M, Zamani Taghizadeh Rabe S, Zamani Taghizadeh Rabe S, Emami SA. A study to investigate the biological activity of proteoglycan mixture extract from Convolvulus arvensis. J Complement Integr Med. 2014;11:265-72.

6. Evans WC, Somanabhandhu A. Cuscohygrine: a constituent of the roots of some British Convolvulaceae. Phytochemistry. 1974;13:519.

7. Jerne NK, Nordin AA. Plaque formation in agar by single antibody-producing cells. Science. 1963;140(3565):405.

8. Cunningham AJ, Szenberg A. Further improvements in the plaque technique for detecting single antibody-forming cells. Immunology. 1968;14(4):599-600.

9. Thakral J, Borar S, Kalia JA. Antioxidant potential fractionation from methanol extract of aerial parts of Convolvulus arvensis Linn. (Convolvulaceae). Int J Pharm Sci Drug Res. 2010;2(3):219-23.

10. Kaur M, Kalia AN. Convolvulus arvensis - A useful weed. I.S.F. College of pharmaceutical sciences and research, Moga Punjab. Int J Pharm Pharm Sci 2012;4(1):38-41.

11. Elzaawely AA, Tawata S. Antioxident activity of phenolic rich fraction obtained from Convolvulus arvensis L. leaves grown in Egypt. Asian J Crop Sci. 2012;4(1):32-40.

12. Khakimova ZZ, Mustanov TB, Mirzokhidov KH. Investigation of anti-inflammatory activity of Convaren in local usage. Med J Uzbekistan. 2013;4(2):99-102.

13. Riordan NH, Menh X, Taylor P, Riordan HD. Anti-angiogenic, antitumor and immunostimulatory effects of a nontoxic plant extract (PMG). Allergy Research Group Focus Newsletter, March; 2001.

14. Calvino N. Anti-angiogenesis properties of a common weed, Convolvulus arevensis. J Chiropr Med. 2002;1:116.

15. Meng XL, Riordan NH, Casciari JJ, Zhu Y, Zhong J, González MJ, et al. Effects of a high molecular mass Convolvulus arvensis extract on tumor growth and angiogenesis. P R Health Sci J. 2002;21:323-8.

16. Khan MU, Ghori NH, Hayat MQ. Phytochemical analyses for antibacterial activity and therapeutic compounds of Convolvulus arvensis L., Collected from the salt range of Pakistan. Adv Life Sci. 2015;2(2):83-90.

17. Schultheiss PC, Knight AP, Traub-Dargatz JL, Todd FG, Stermitz FR. Toxicity of field bindweed (Convolvulus arvensis) to mice. Vet Hum Toxicol. 1995;37(5):452-4.

Cite this article as: Porsokhonova K, Agzamov R. Investigation of Convaren's stimulating effect on immune organs of mice. Int J Basic Clin Pharmacol 2015;4:657-9. 